\title{
Field Study at Seloliman Village in East Java using Kali Maron Micro Hydro Power Plants as Power Supply
}

\author{
Haksari Laksmi Bestari, I N Satya Kumara \\ Department of Electrical Engineering Udayana University \\ Jl.Raya Kampus Unud Jimbaran, Bali, Indonesia \\ Email : haksarisariegmail.com
}

\begin{abstract}
Indonesia has enormous water resources potential up to $75,000 \mathrm{MW}$ and currently uses as a national power plant that reached $11.56 \%$ of the total potential, or equal to $8,671 \mathrm{MW}$. Indonesia's electrification ratio in 2017 reached $88.5 \%$, which means there are $11.5 \%$ of households in Indonesia who have not had access to electricity. Micro Hydro Power Plant (MHPP) is one alternative solution that can produce electricity and has been widely used, particularly in rural areas in Indonesia. The magnitude of the role of electricity in people's lives have encourage the authors to study of Kali Maron MHPP community based that currently still operates and can determine the impact of electricity from MHPP for people's lives. This research used qualitative method with descriptive analysis. The data collection by observation and interview. Observations were made on Kali Maron MHPP and the life of the community users of Kali Maron MHPP. While the interviews were conducted with 20 household electric users of Kali Maron MHPP, each respondent is a husband or a wife and also manager of Kali Maron MHPP

Kali Maron MHPP was established in 1994 that still operating until now and utilizing the Maron river potential with debit $0.3 \mathrm{~m}^{3} /$ sec and head $14 \mathrm{~m}$ to generate power of $25 \mathrm{~kW}$. Kali Maron MHPP deliver power supply to 66 users and the rest of the power is sold to PLN Kali Maron MHPP is MHPP community based operated power plants that stil operating properly under the manages of Paguyuban Kali Maron (PKM). Paguyuban Kali Maron (PKM) manages the Kali Maron MHPP that consisting of advisory, management board and daily executive. The daily executive consists of a chairman, a secretary, a treasurer, and two operators. The use of the MHPP has implications for the economic and social life of the community. The economic aspects increase in income and the increase in people's living. While the social aspects seen from the rise of education, information facilities, and religion.
\end{abstract}

Keywords- Renewable Energy, Microhydro, MHPP, Economic Impact, Social Impact

\section{INTRODUCTION}

Indonesia has abundant natural resources, including energy resources in it. Indonesia has enormous water resources potential up to 75,000 $\mathrm{MW}$, and currently uses as a national power plants that reached $11.56 \%$ of the total potential, or equal to $8,671 \mathrm{MW}$ [1]. The percentage of utilization of water resources in the place indicates that there are still many locations in Indonesia that have the potential to be utilized as a power plant. Based on the blueprint energyof Indonesia stated that hydropower is part of the role of the national renewable energy by 2025 will increase its contribution to $5 \%$ of the national energy mix and other renewable resources [2]. The potential of hydropower in Indonesia include lakes, rivers and waterfalls which are found in the Indonesian island, including Java.

Indonesia's electrification ratio reached $88.5 \%$, which means there are $11.5 \%$ of households in Indonesia who have not had access to electricity [3].

At this time the electricity is an important requirement in human life. Almost all of the equipment that supports the daily human activities both at the domestic, industrial and offices and schools or other public facilities use electricity. Most of the Indonesian people who enjoyed access to information and communication are also very dependent on the availability of electricity. Therefore, the electrical energy can be notarized absolute necessity for the daily activities of the people of Indonesia.

Micro Hydro Power Plant (MHPP) is one alternative solution that can produce electricity and has been widely used, particularly in rural areas in Indonesia. MHPP does not significantly affect the environment or reduce water for agricultural purposes. MHPP development does not require extensive land and does not require any fuel.

In 1993, the village Seloliman is one of the villages in the district of Trawas, Mojokerto, East Java that already have access to electricity. But there is only Janjing hamlet that has not access the electricity from PLN grid, because transportation acces to this hamlet is very difficult and steep. It is also less efficient because only about 24 households are the community of this hamlet. So in 1994 began to established a MHPP that still operates with the power capacity of $25 \mathrm{~kW}$. The magnitude of the role of electricity in people live encourage the authors to study of Kali Maron MHPP community based that currently still operates and can determine the impact of electricity from MHPP for people's gives. 


\section{LITERATURE}

\section{A. MHPP}

Micro Hydro Power Plant (MHPP) is one of small scale utilization technology of water energy that environmental friendly. Micro Hydro Power Plant (MHPP) is a power plant using water as prime mover, such as irrigation canals, rivers or waterfalls, by utilizing high waterfall or head (meters) and debit $\left(\mathrm{m}^{3} / \mathrm{sec}\right)$. The electrical energy generated from the conversion of kinetic energy or potential energy, through the conversion tool (turbine and generator) which is then distributed to users.

Micro hydro power plant consist of a civil component, mechanical components and electrical components. Civil component consists of a diversion weir, an intake, a headrace, a sand trap, a spillway, a forebay, a trash rack, a penstock, a power house, and a tailrace. While the mechanical-electrical component consists of a turbine, a generator, a control panel, and a ballast load.

\section{B. Rural Electrification Program}

Development of rural electrification is the government's duty to provide electrical service to rural communities. Considering the main network of the Perusahaan Listrik Negara (PLN) has not been able to supply $100 \%$ rural electrification needs, then there is still great potential to develop the electricity in the outside network by using renewable energy. Ministry of Energy and Mineral Resources (MEMR) issued Ministerial Decree No.1122 K /30 /MEM/2002 on the Distributed Small Power Plants (Distributed Generation) on June 12, 2002 to ensure the availability of electricity in providing business opportunities for small scale electricity producers taking renewable energy to sell electricity to PLN at a price that is standardized, with a maximum total installed capacity of $1 \mathrm{MW}$. Renewable energy sources are covered by the decision include wind, solar, mini/micro hydro, agricultural products or industrial waste, dendro-thermal sources (wood) or geothermal energy. This decision is intended to stimulate the private sector such as local government to find a potential production of renewable energy for electricity generation.

Ministry of Energy and Mineral Resources of the Republic of Indonesia issued a regulation No.10 of 2017 on the Principles in the Power Purchase Agreement. This Ministerial Regulation regulates the main points in the Power Purchase Agreement between PT PLN (Persero) as a buyer and Enterprises as a seller in Electric Power System. Included in this type of generator is geothermal power plant, hydro power plant and biomass power plant [4].

Based on Regulation No.12 of 2017 on Utilization of Renewable Energy Sources for Electricity Supply Regulation of the Ministry of Energy and Mineral Resources on Utilization of Renewable Energy Sources for the Electricity Supply. This Ministerial Regulation is a guideline for PT PLN (Persero) is purchasing power from power plants utilizing renewable energy sources. Renewable energy sources that mean are solar, wind, hydropower, biomass, biogas, municipal solid waste, and geothermal [5].

The selling price of electricity generation from Distributed Generation (DG) is the price at the point of interconnection with the system PLN. Its selling price is $80 \%$ of the production cost per $\mathrm{kWh}$ (HPP) is connected to medium-voltage grids and 60\% HPP, when selling electricity under non-company capacity. Ministerial Regulation No.002/2006 was issued to regulate the electric power medium-scale enterprise (1-10 MW) that use renewable energy. Both of the above regulations revised through the Ministry of Energy and Mineral Resources No. 31/2009 which sets the Purchase Price of Electricity by PT PLN (Persero) of Small and Medium Scale Power Plants Using Renewable Energy Or Excess Power. Ministerial Regulation No. 12 in 2017 set a standard price of the purchase of electricity from renewable energy sources a maximum of $85 \%$ of the Cost of Supply generation in areas where power plants operates.

The general objective of the electrification for rural areas, is an effort in providing electricity to villages, especially for developing countries. Can be prepared several important factors in its execution, is as follows first the use of electricity for productive purposes (economic). Rural electrification generally focuses on efforts to generate or enhance the community productive activities. One of the productives activities of electricity usage is to do activities such as irrigation pumps, rural industries, small workshops, farm equipment, refrigeration facilities, etc. This increase in productive activity will ultimately increase the number of jobs, agricultural production, and other services, so it can increse the income of the population [6].

The second factors is social benefits. The rural electrification program from the social aspect aims to assist the disadvantaged groups, the expansion of access to electricity services in areas not yet reached by electricity, and encourage economic development and growth and improve the welfare of rural people. Social benefits can also be felt like an increase in education such as reading and learning, improving people's health level, facilitate and accelerate the public to obtain information from electronic media and other communication media.

Aspects of ownership and knowledge of the technology also can not be separated from attention. Due to the ownership society will be felt to have, maintain, and care for these technologies. So with the knowledge of technology, which will be able to equip and help the community to know how this equipment works and repair in case of damage. The existance of a society based on this sense, then the system can be used in the long term and indirectly can reduce the use of fuel as a source of traditional light fuel [6].

\section{METHODOLOGY}

This research uses qualitative method by conducting descriptive analysis. Qualitative research tries to understand the phenomenon of what is experienced by the subject of research by describing the facts in general. The focus of data 
analysis is only done for technical studies of MHPP and the impact of electricity on people's lives, in this case the household and the environment.

The data collection was done by observation and interview. Observations were made on Kali Maron MHPP and people's life of MHPP Kali Maron electricity users. While interviews were conducted on 20 households of electricity users MHPP Kali Maron, with each respondent is husband or wife and also the manager of MHPP Kali Maron. While the secondary data taken from the various literature.

\section{Kali Maron MHPP}

MHPP Kali Maron is located in Biting hamlet, Seloliman village by using water power from Maron river. The word "kali" comes from the Javanese language, which means the river, so the plant is better known as the MHPP Kali Maron. Figure 1 shows the location of Kali Maron MHPP.

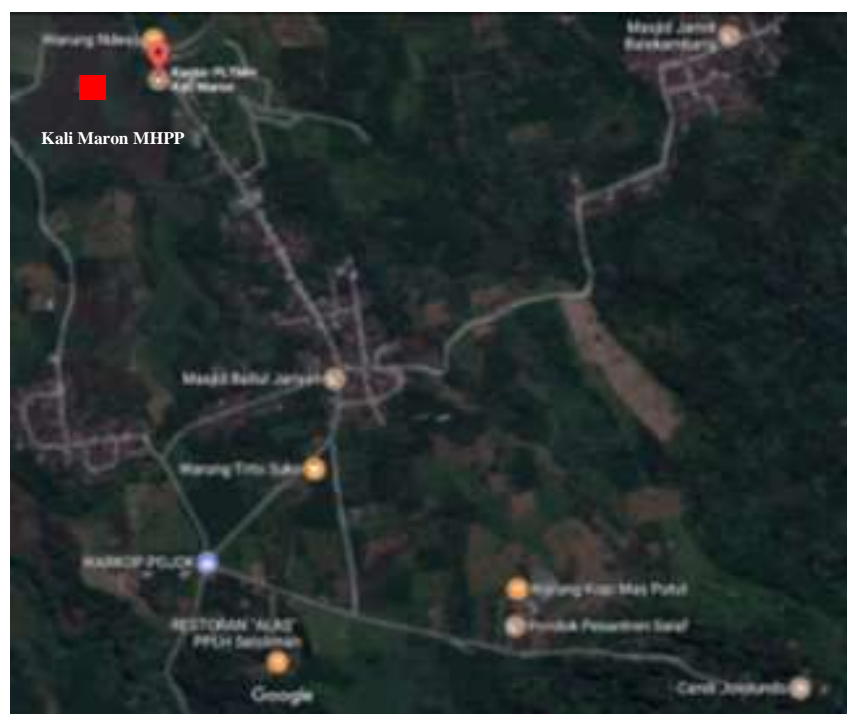

Figure 1. Map Location of MHPP Kali Maron (Source: Google Maps, 2017)

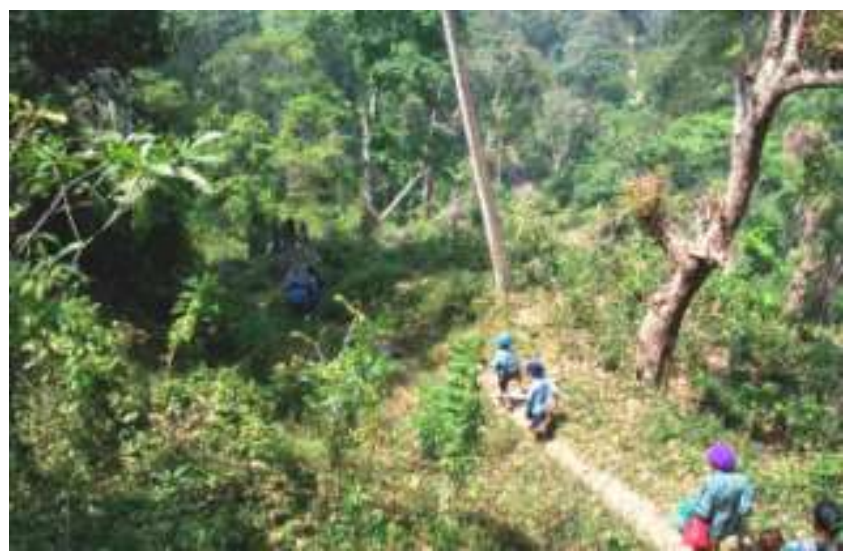

Figure 2. Access Road to Janjing Hamlet (Source: Society of Kali Maron)
In 1993, Seloliman community were able to enjoy access to electricity from grid PLN (Perusahaan Listrik Negara). However, there is one hamlet, Janjing hamlet that has not got access to electricity, due to its location away from the highway and need to pass through the forest valley and less economical where the number of head of Janjing family at that time as much as 24 households.

In 1994, with the help of donors and non-governmental organizations, MHPP Kali Maron was built with a capacity of $12 \mathrm{~kW}$. The purpose of this MHPP development is to fulfill the electricity needs of Janjing hamlet community, to fulfill the need of lighting and operation of office equipment in PPLH Seloliman, and also as a learning media for general public about renewable energy management

In 2000, the capacity of MHPP was upgraded to $25 \mathrm{~kW}$ and a non-governmental organization called Paguyuban Kali Maron (PKM) was established as the managers. In order to increase the efficiency of MHPP Kali Maron, especially for the community of Seloliman, PKM developed an electrical interconnection system to State Electricity Company with named Perusahaan Listrik Negara (PLN) through EMR Ministerial Decree No.1122 K / 30 / MEM / 2002 dated June 12, 2002. So in 2003, the interconnection of MHPP Kali Maron with PLN grid in the framework of the implementation of distributed generation (DG) has been inaugurated by Luluk Sumiarso as Director General of Oil and Gas, Ministry of Energy and Mineral Resources.

Maron river has the potential to be utilized as the MHPP so it can be an effort to fulfill electrical energy in Seloliman village, especially in Janjing hamlet. The water requirement utilized for MHPP is obtained from the flow of Meron river which is deflected to the side of the river and flowed to the location of the power house and will be returned to the original river flow after through the turbine. So that the irrigation needs of residents will still be fulfilled and not disturbed by the existance of this MHPP. The potential of the Maron river used for MHPP Kali Maron is a water flow of 0.3 $\mathrm{m}^{3} / \mathrm{sec}$ and head $14 \mathrm{~m}$ which can be used to generate power by $25 \mathrm{~kW}$ [7].

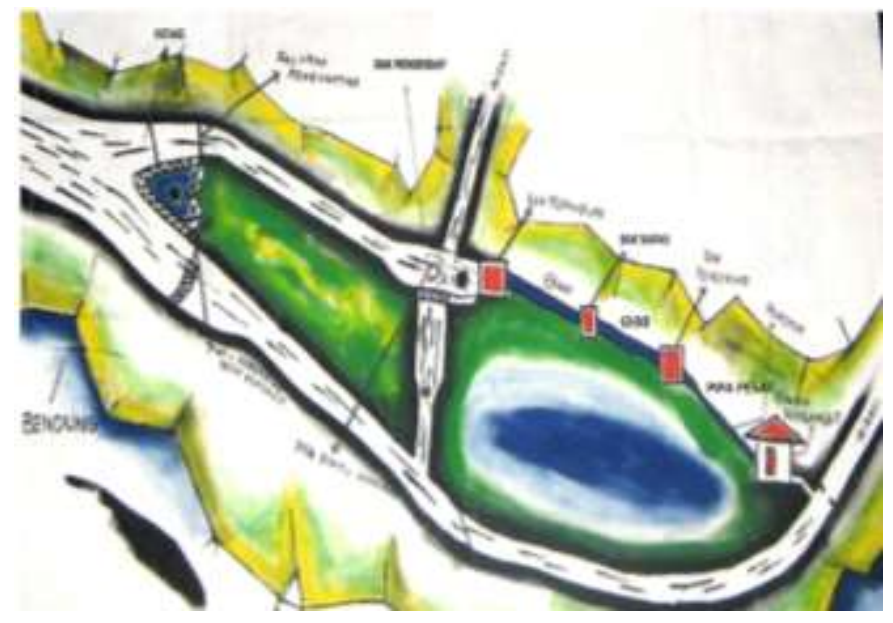

Figure 3. Scheme of MHPP Kali Maron (Source: Society of Kali Maron) 
The process of generating power on the generator starts from the water source that comes from nature that collect and flow as a river. The water flow used from the Maron river which subsequently water from the river is dammed and flowed into the intake to be distributed to the headrace. The sediment from the headrace is collected in the sand trap and water on the surface will enter to the container tank after being first filtering by the trash rack. The water in the container tank is distributed into breath tank which then continued to forebay before being flowed into the turbine through the penstock. The water from the penstock is used to turn the generator, so it can generate electricity. The water already used to rotate the turbine is then discharged back into the river through the tail race. The power output from the generator is supplied to the Electronic Load Controller (ELC) to be controlled which will then be forwarded to Mainscon Module to be supplied to the users and the remaining power is interconnected to the PLN medium voltage grid. In each user's homes already installed electricity meters as a means of control of the user's electricity consumption. So that can know the amount of power used by each home in units of kilowatt hour $(\mathrm{kWh})$.

The main components of Kali Maron MHPP consists of a turbine, a generator, a control panel, a synchronizing panel, and a transformer.

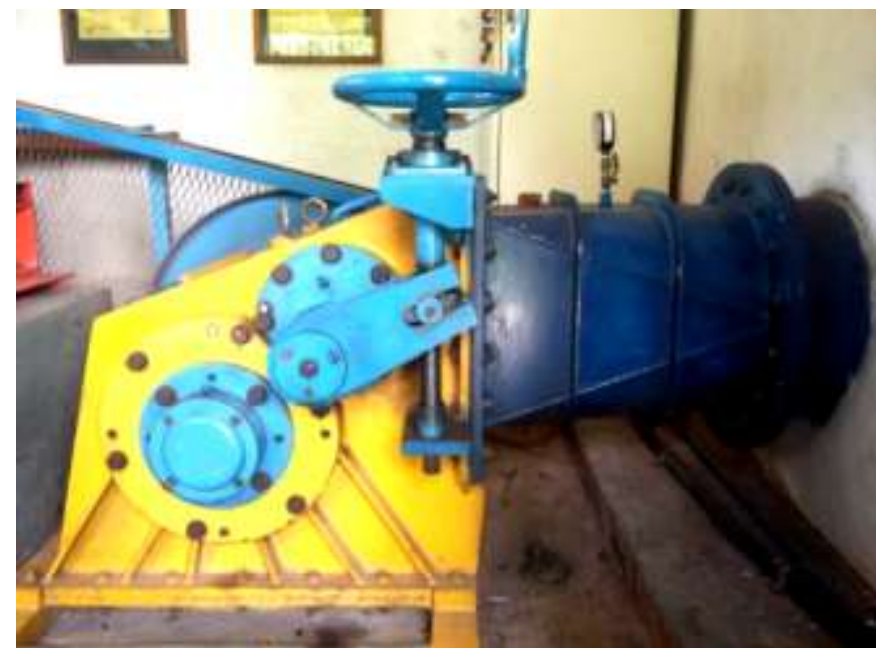

Figure 4. T-14 Crossflow Turbine

The turbine used to rotate the generator is a crossflow type T-14 D300 from PT.Heksa Perkasa. This type of turbine converts all the potential energy of water into kinetic energy that will rotate the turbine, thus producing a torsional energy.

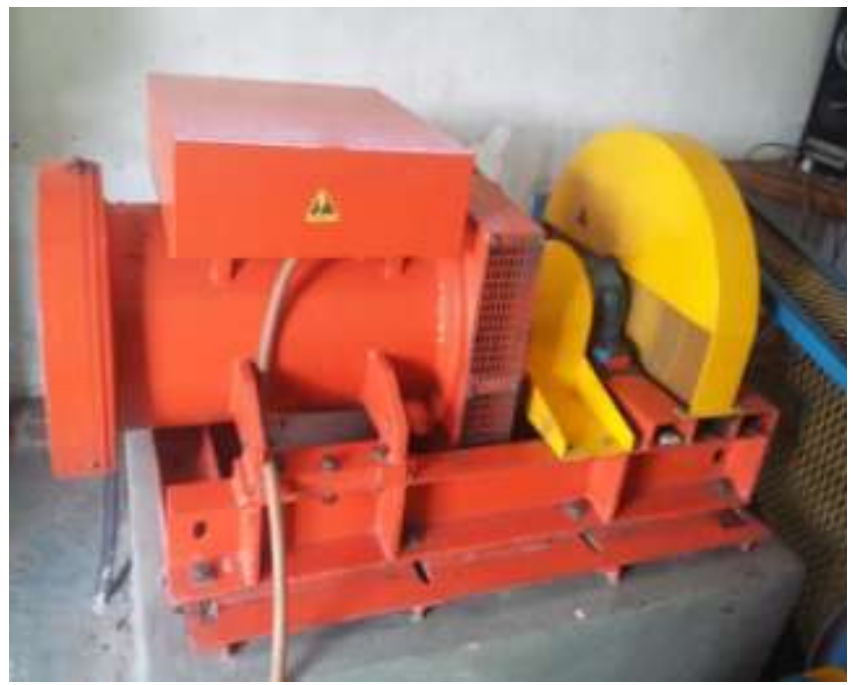

Figure 5. Generator Synchronous

Generator used as a power plant at Kali Maron MHPP that is 3 phase synchronous generator with own amplifier or own excitation. The power rating of the generator is $40 \mathrm{kVA}$ with a rotational speed of $1500 \mathrm{rpm}$.

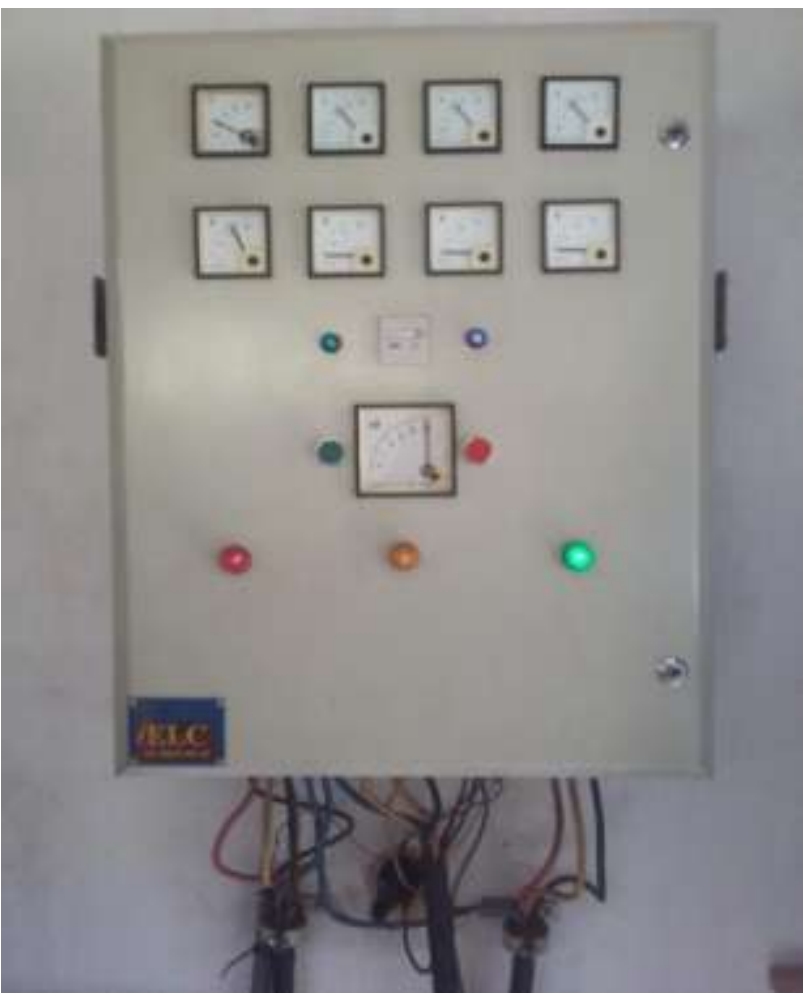

Figure 6. Kali Maron Electronic Load Controller

The control systems used in Kali Maron MHPP is Electronic Load Controller (ELC) type. This control system serves to adjust the load to be equal to the power generated by the generator. The workings of this control system at the time of stand alone is to balance the power at the generator and the users load by switching the excess power of the generator to the ballast load to maintain the frequency stability. 
Meanwhile, if in the interconnection condition then the excess power generator will be forwarded to the synchronization panel to be distributed to the PLN grid.

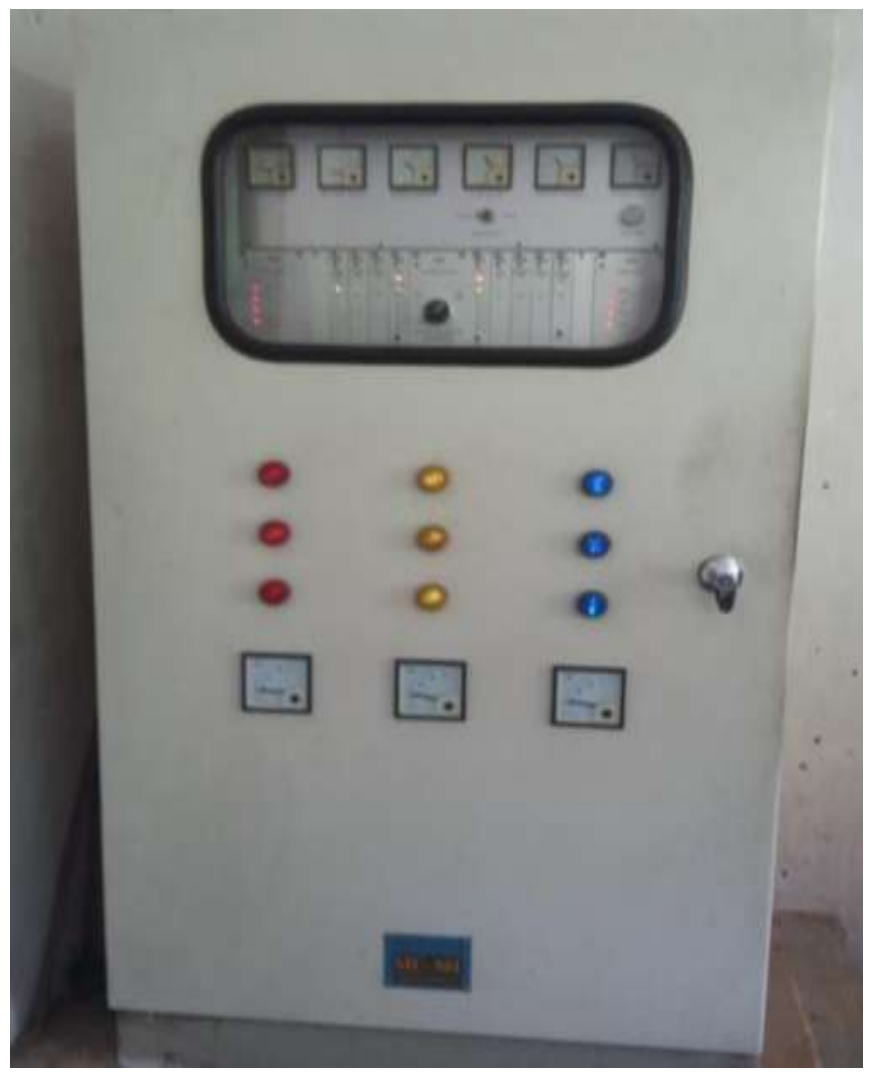

Figure 7. Kali Maron Synchronizing Panel

This mainscon module is a synchronization panel that is used as a controller as well as protector generator when in interconnection condition with PLN grid. By using this panel, power generation can be optimized without any power being discharged into the ballast.

PKM consisting of advisory, management board, and daily executive. The daily executive consists of 4 people from the communities of Seloliman village themselves as the manager. The daily executive consists of one person who currently serves as chairman and treasurer, 1 person as secretary, and 2 person as the generator operators. The daily executive is tasked to manage, operate, up to sell electricity to consumers MHPP. With the existence of this community, the community will feel more owned, maintain and care of the technology of the power plant. Based on the taste, the MHPP system community based can be used for longer. Kali Maron MHPP is still operating since 1994 until now.

\section{IMPACT ON ELECTRICITY KALI MARON MHPP TO THE LIFE OF THE VILLAGE COMMUNITY}

In 2000, a non-governmental organization called Paguyuban Kali Maron (PKM) was established as the managers of the Kali Maron MHPP. In 2017, PKM serves 66 users and sells the remaining power to PLN grid [8]. The users list compiled from existing data in the PKM are shown in Table 1.

Table 1. Installed Load of Kali Maron MHPP

\begin{tabular}{|c|c|c|}
\hline No. & Installed power & Number \\
\hline 1. & $450 \mathrm{VA}$ & 46 \\
\hline 2. & $900 \mathrm{VA}$ & 13 \\
\hline 3. & $2200 \mathrm{VA}$ & 6 \\
\hline 4 & $3500 \mathrm{VA}$ & 1 \\
\hline \multicolumn{2}{|c|}{ Total } & 66 \\
\hline
\end{tabular}

To determine the impact of MHPP on community life, the authors conducted interviews to 20 users and manager of Kali Maron MHPP. Interviews were conducted by providing questions such as the list of electronic equipment that is owned, the type of work, the effect on the income of the community, the effect on regional development, the effect on improving the welfare of the community, improving the information facilities, and the mechanism of payment ocontributions of MHPP electricity.

From the results of interviews with 20 users and manager of Kali Maron MHPP, most people feel the addition of electronic equipment in their homes. Once the electricity MHPP illuminate the village, then almost every family made additional electronic equipment such as buying a television, ricecooker, and other electronic equipment. Rice originally be cooked using a stove or oil stove, now almost entirely change using rice cooker. Likewise with fans, mobile phones, radios, speakers and other electronic items that are not necessarily primary needs of the community are now beginning to meet every home stay.

The addition of electronic equipment such as televisions, radios, and mobile phones shows that there is an increase of information facilities for the community. So that people become easier to access information widely through the electronic media.

People that initially only work as farmers and ranchers, now with the power supply of the MHPP can increase their income. So that people can have other proffessions such as opening shop, food stalls and furniture business. In addition, there are also small businesses such as cotton blower and SEMPEDU business (Sempur Peduli Daur Ulang Kertas). This cotton blower business is managed by the youth village in Sempur hamlet which is then sold to Biting hamlet to produced into the pillows, mattresses, and bolsters. While the paper recycling business is managed by housewives in Sempur hamlet, where recycled paper products such as certificate, pencil case, and other souvenirs that will be sold to PPLH Seloliman. But now, the paper recycling businesses is no longer operational because there is no people to manage it.

There are two house of prayer and 2 boarding schools, from 66 users of this MHPP. The house of prayer that means are mosque. Boarding school is a place for the students to learn about the science of religion to their teachers. This boarding school is a boarding house with a building that shows its simplicity. The addition of the construction hous of prayer and boarding schools in this village shows that there is 
an increase in the prosperity of the community in terms of education and religion.

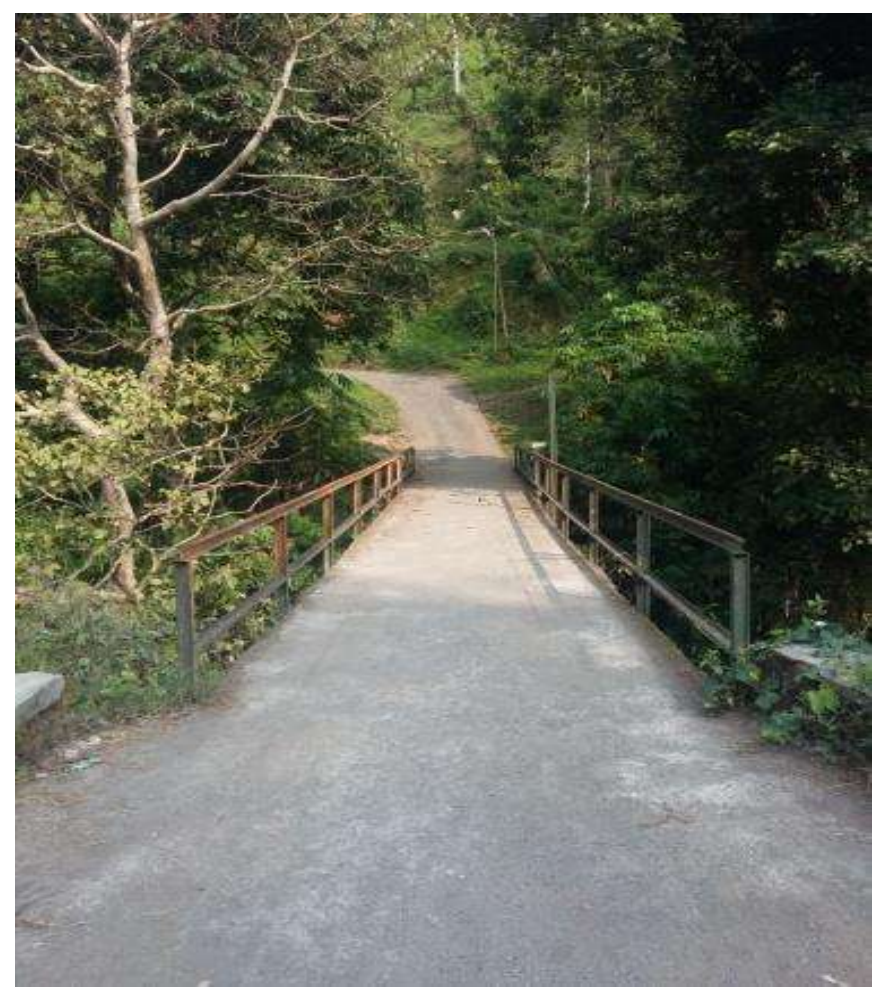

Figure 8. New Bridge Access to the Janjing Hamlet

In 1993, access to Janjing hamlet must pass through a forested valley and the bridge made of bamboo. After the Kali Maron MHPP managed by PKM, the bamboo bridge was renovated and built a new bridge from concrete. The Janjing hamlet peoples is working together to built a new bridge that was built in 2005 with the funding support from PKM. The construction of this bridge showed an increase in the region's infrastructure.

The basic electricity tariff mechanism has been estavlished by the managers of Paguyuban Kali Maron (PKM). The recording of payments is done at the end of each month by PKM members by surveying and recording the number of kilowatt meters from each house. Electricity payment time is made mid-month around the $10^{\text {th }}$ to the $20^{\text {th }}$. Payments can be made to the PKM office or to the home of the daily executive chairman in the Janjing hamlet. Recording of payments can be done well, but there is still a problem that is quite worrying, especially from users who are still there are many users late in paying the monthly contributions. This of course resulted in the delay of income for the manager. The manager also felt less able to be firm to the users, which is caused by social factors between the community.

\section{CONCLUSION}

Based on discussion on the previous section following conclusions can be drawn :
1) Kali Maron MHPP was established in 1994 that still operating until now and utilizing Maron river potential with debit $0.3 \mathrm{~m}^{3} / \mathrm{sec}$ and head $14 \mathrm{~m}$ to generate power of $25 \mathrm{~kW}$. Kali Maron MHPP deliver power supply to 66 users and the rest of the power is sold to PLN. Kali Maron MHPP is MHPP community based operated power plants that still operating properly under the manages of Paguyuban Kali Maron (PKM).

2) Paguyuban Kali Maron (PKM) manages the Kali Maron MHPP taht consists of advisory, management board, and daily executive. The daily executive is composed of a chairman, a secretary, a treasurer, and two operators.

3) The use of the MHPP have implications for the economic and social life of the community. The economic increase in income and increase in people's living. While the social aspects seen from the increase in education, information facilities, and religion.

\section{REFERENCES}

[1] U. Priyanto, Outlook Energi Indonesia 2015, Jakarta: Badan Pengkajian dan Penerapan Teknologi, 2015.

[2] Sekretariat Panitia Teknis Sumber Energi, Blueprint Pengelolaan Energi Nasional 2016-2005, Jakarta, 2006.

[3] Presiden Republik Indonesia, "Lampiran I Peraturan Presiden Republik Indonesia Nomor 22 Tahun 2017 Tentang Rencana Umum Energi Nasional," Jakarta.

[4] Menteri Energi dan Sumber Daya Mineral Republik Indonesia, "Peraturan Menteri Energi Dan Sumber Daya Mineral Republik Indonesia Nomor 10 Tahun 2017 tentang Pokok-pokok dalam Perjanjian Jual Beli Tenaga Listrik," Jakarta.

[5] Menteri Energi dan Sumber Daya Mineral Republik Indonesia, "Peraturan Menteri Energi dan Sumber Daya Mineral Republik Indonesia Nomor 12 Tahun 2017 tentang Pemanfaatan Sumber Energi Terbarukan Untuk Penyediaan Tenaga Listrik," Jakarta.

[6] I. M. A. Nugraha, I. A. Dayu and I. N. S. Kumara, "Studi Dampak Ekonomi dan Sosisal PLTS Sebagai Listrik Pedesaan Terhadap Masyarakat Desa Ban Kubu Karangasem," in Prosiding Conference on Smart-Green Technology in Electrical and Information System, Bali, 2013.

[7] Paguyuban Kali Maron, "Usulan Penerapan PSK Tersebar Pembangkit Listrik Mikro-hidro Desa Seloliman, Kec. Trawas, Kab.Mojokerto, Jawa Timur," Mojokert, 2003.

[8] Paguyuban Kali Maron, Buku Catatan Pelanggan Tahun 2017, Mojokerto, 2017. 